\title{
Lucyna Chmielewska
}

University of Lodz, Faculty of International and Political Studies

Department of Theory of Politics and Political Thought

e-mail: lucychmielewska@uni.lodz.pl

\section{The economic ethics of Calvinism The reconciliation of piety and wealth*}

\begin{abstract}
The doctrine of predestination in the Lutheran and Calvinist theology, along with the assumption of a radical separation of nature and grace as well as the material and spiritual realm, had a significant impact on social life. The salvation of the soul, the soteriological dimension of human destiny, remained dependent on the grace of God (predestination), undeserved and unfathomable. The earthly reality, the institution of the Church and good works could in no way contribute to the salvation of the soul. Martin Luther, especially at the initial stage of his reformation activities, focused on private spirituality, considering the earthly dimension of reality to be the domain of the secular power. John Calvin and his successors justified in their teachings a different attitude manifested in the interest in the earthly world based on religious ethics. The doctrine of predestination, therefore, did not result in, as one would expect, quietism but in activism. The Calvinists believed that predestination was not manifested in single good deeds but in a certain methodology of systematised life based on religious ethics. Religiousness was supposed to be expressed through activity in the world and was meant to show the glory of its Creator. Work, thrift and honesty were supposed to lead to the rebirth, i.e. "sanctification" of the world, and were the essence of what Max Weber called the spirit of capitalism. Calvinism led to changes in the approach to such economic issues as money lending at interest, work or enrichment.
\end{abstract}

Keywords: Calvinism, predestination, social and political thought, work, capitalism JEL Classification: A13, Z12

\footnotetext{
* The article is an updated version of the paper published in Polish in the Annales. Ethics in Economic Life 19(3), 35-46.
} 


\section{Introduction}

Medieval thought perceived economic issues as part of morality which was derived from theology. All earthly pursuits of people were evaluated through the prism of one system based on the hierarchy of values whose nature was determined by the spiritual destiny of mankind - salvation. Economic transactions were less market-related and more related to moral standards derived from the Catholic religion. Economic issues were of not much interest to scholastic philosophy. One may find it interesting that this philosophy for centuries considered the problem of ownership, attempting to determine whether it had a natural character or whether it resulted from convention, i.e. it was based on positive law. This intellectual dilemma has never been resolved. The Reformer Martin Luther found intellectual scholasticism offensive. Regarding the issue of ownership, he allegedly concluded that it was pointless to consider something which could not be solved through reflection (Rothbard, 2006, p. 139). A significant change in the approach to economic issues was introduced by the Reformation. It abolished the hierarchy of the Church organisation, and as a result, also the traditional formulas of thinking about the world. Lutheranism, compared to Catholicism, was characterised by far more developed democratism of religion (the priesthood of all believers). However, in terms of social issues, including the approach to economic activity, it did not go beyond the established doctrine of the Catholic Church, for example, its rigorous treatment of the profit obtained from money lending at interest. Major changes in thinking about the economic sphere were brought about by Calvinism. ${ }^{1}$ However, it would have been impossible without the pioneering theology of Mar-

\footnotetext{
${ }^{1}$ The concept of "Calvinism" is generally associated with the religious ideas professed by religious communities and individuals under the influence of the teachings of John Calvin. The term "Calvinism" as related to the religious worldview of the followers of Calvin suggests a direct link between Calvin and the thought of his successors. This relationship, however, is complex as Calvin was not the sole creator of Calvinism, i.e. the Reformed Tradition. Calvin's theology in the Reformed Tradition never had a regulatory status, in contrast to the legacy of Luther which had an undisputed position among the Lutheran confessional communities. The Reformed Theology was expressed in several documents, such as the First and Second Helvetic Confession, Consensus Tigurinus (Consensus of Zurich), the Heidelberg Catechism, the Belgian Confession, the Canons of Dort and the Westminster Standards. Those documents expressed the collective thought and were products of particular communities and circumstances in which they found themselves, not the thoughts of a specific person. The concept of Calvinism, forged by the Lutherans as a polemical tool to damage the reputation of the Reformed Protestants, is not a good instrument for analysing modern thought. The terms Reformed Theology and Reformed Orthodoxy are definitely better suited for this purpose, as they reflect the fact that the so-called Calvinists continued the thought not only of Calvin but also of other reformers, creating the tradition of the Reformed denominations. Calvin was an important but not the sole or dominant source of this tradition (Trueman, 2004, pp. 225-226). The use of the term "Calvinism" in relation to the whole of Reformed Theology is acceptable and convenient, but not quite correct, as it implies the movement focused primarily on incorporating the intellectual legacy of Calvin. It can be proven, however, that scholars from a historical point of view referred to as Calvinists maintained freedom in their views to use the theological and methodological sources other than the writings of Calvin. According to Alister McGrath, the biographer of the Reformer from Geneva, Calvin could remain the most important star on the Calvinist firmament, but there were others who modified his thought and method with their own thoughts and methods (2009, p. 294).
} 
tin Luther from which the religious roots of Calvinism sprang, though in terms of knowledge about the world surrounding man Calvinist teachings introduced a completely new quality.

The aim of the article is an attempt to answer the question concerning the nature of innovativeness found in the Calvinist approach to basic economic issues, such as money circulation or labour, and their theological grounding. The author assumes that the doctrine of predestination and the original sin resulting from the theological conviction of the radical separation of the grace of God and nature (the spirit and the matter). This has been the key doctrine of Protestantism, including Calvinism, and it was significant for the Calvinist social teachings. The change of approach to money lending at interest, called usury at the time, and to work, especially physical labour, is a result of the theological assumption about the ineffectiveness of human worldly deeds for the receipt of God's grace necessary for the salvation of the soul. The doctrine of predestination stating that salvation comes only by the grace of God, not as a reward for good deeds, did not lead to apathy and inactivity but instead increased involvement in the worldly affairs.

Due to its limited size, the text presents in a simplified manner the main theological motivation important from the point of view of the aim of the article and the attitude of the followers of Calvinism towards economic issues. It is worth noting that the economic topic was a sort of marginal theme for the Protestant Calvinist thinkers, significant not from the theological point of view, but due to the fact that the followers of Calvinism were among those social groups that were the most interested in changes in the approach to economic issues.

The relationship between Calvinism and the development of modern capitalism was detailed by Max Weber in The Protestant Ethic and the Spirit of Capitalism (1905), thereby giving rise to the ongoing debate over the influence of Calvinism on the modern West. Weber did not expand the dominant in Protestantism theme concerning the awareness of the dualism of nature and grace, and the material and spiritual world. The said dualism came from the doctrine of the original sin and was important for the formation of the social life of the followers of Calvinism. This was put forth by Richard H. Tawney in Religion and the Rise of Capitalism. A Historical Study, in 1926, which complemented Weber's theories.

The article is a review and analysis of selected texts by Martin Luther and John Calvin.

\section{Protestant dualism of matter and spirit}

A starting point for the examination of the issue, i.e. Calvinist economic thought, is the theological doctrine of the original sin, a strong feature of Lutheranism and Calvinism. In the theology of Martin Luther, the original sin was presented as an event dramatic in its consequences for humanity which had lost the opportunity of the love of God, and therefore of doing good. Contrary to the Catholic theology that regarded the original sin only as the cause of the damaging and weakening of 
human nature, Luther argued that the sin of the first parents has resulted in a total degradation of humanity. People retained only the capability for sin (1517, theses 4-7), and a propensity for evil, and they were incapable of loving God (theses 13, 16-18), lacking any faith or goodness. They lost the correct precept and good will (thesis 34). Man can do good only by the grace of God, i.e., predestined. According to Luther:

Not that the righteous person does nothing, but that one's works do not make him or her righteous, rather that one's righteousness creates works. (thesis 40)

The grace of God meant that the fulfilment of the moral law became a source of pleasure for the predestined (theses 73-75). As a voluntarist, Luther attributed to God infinite omnipotence and did not recognise the existence of the free will of man. In the face of the corruption of human reason and will, it was impossible to speak of the truth of human cognition and the freedom of human actions. Reason, helpless in its search of truth, was perceived as blind and devoid of knowledge, unable to indicate the will to do righteous things, thus man was incapable of doing good. Mind was in error; the will was broken. This anthropological pessimism led to the thesis about justification (salvation) only by grace (sola gratia) and about the worthlessness of human actions in this matter (Hervada, 2013, p. 130). In thus formulated order of salvation, the law, including the law of nature, seemed unnecessary, as the order of grace and faith did not require it. Similarly, the order of law, including the law of nature, was considered as unrelated to the question of the salvation of the soul, and related exclusively to earthly life. The presented stance was related to the theory of the two kingdoms of St. Augustine, based on severing the unity between the natural and the supernatural realm. The goal of the spiritual kingdom, i.e. the salvation by the grace of God and the resulting faith, was in no way associated with the goal of the earthly kingdom - earthly life of man. The connection between those two realms had been broken. The spiritual realm was ruled by the Word of God, while the earthly realm by the law of nature and the statutory law (Hervada, 2013, p. 131).

According to Luther, God was not speaking through the priesthood or the institutions created by the human hand, but directly to the human heart and only to it. The previously existing mediation between the realm of the spirit and the realm of the senses had become obsolete, as the human soul did not need for its salvation institutions "of this world", created by people. It was the communion with the Creator that was important for the soul. The material world and social relations could not in the slightest ease the soul's reception of the grace of God. As a consequence of the original sin, they became a sphere of chaos and cruelty, an unsanctified desert unsuitable for sanctification. The external, material realm was deprived of any influence on the Christian religiousness, which opened the door to its "secularisation" and the separation of the spiritual and the secular realms that previously coexisted in a close relationship based on the assumptions of Thomism 
about the grace of God complementing and enriching earthly life. According to the Protestants, the only thing that enriched earthly life and Christianity was the revealed Word of God (Tawney, 1926, pp. 96-97).

Such an important religious change introduced by Luther and the intellectual paths leading to it are matters for theologians' considerations. However, the effect of that religious change on social teachings was tremendous. Since salvation became solely dependent on the influence of the grace of God on the soul of an individual, then the entire religious organisation acting as an intermediary between the soul and its Creator in the form of institutions, systematic worship and the Church hierarchy became unnecessary. It dismantled the medieval notion of the hierarchy of values as relating to the common spiritual goal and society as a body consisting of members labouring in a wide range of activities to achieve that spiritual goal. Grace no longer complemented nature but became its opposite. Man's activity as a member of society was no longer considered as an activity of the child of God, since the matters of the world ceased to influence salvation; deeds lost their soteriological meaning. For Christians, the Bible and their own conscience were supposed to be a sufficient guide. Potentially, everybody could be predestined, but only the spiritual sphere, the human soul, could participate in predestination. The consequence of Luther's theological reasoning was a radical division of the material and spiritual realm (Tawney, 1926, p. 98). The material realm was incompatible with the spiritual realm, and regulations issued by religious or secular institutions did not matter for the Christian ethic. The heart of a Christian could be guided only by the dictates of the gospel, without coercion (Tawney, 1926, p. 100). A peculiar side effect of creating the theological assumption of worthlessness of the earthly world (nature) and human deeds for the salvation of the soul was the liberation of the earthly reality from spiritual obligations. Worldly affairs, including economic activities, which used to be tied to religious commandments, could follow their own path and develop according to their own rules. In this process, the second denomination of Protestantism-Calvinism, which brought the religious ethics into the world, proved useful. From now on, it was to serve the development of earthly reality, which though devoid of the grace of God, remained to be one of God's creations. The duty of man should be taking care of the world, the work of the Creator, and the mitigation of the consequences of the original sin.

\section{Calvinist affirmation of the world and the spirit of capitalism}

Calvinism grew out of Lutheranism, adopted the principles of sola scriptura, sola fide and sola gratia, and continued Luther's doctrine on the separation of the earthly and spiritual realms. This did not, however, result in a detachment from the earthly reality, as was largely the case in Lutheranism. The area of interest of John Calvin was not only the spiritual sphere of individuals but also their external environment. The Reformer from Geneva recognised the need of reconstruction of the 
institutional Church rejected by Luther in favour of private religiousness and of the renewal of society by taking religious control over private and public life. Calvinism was to be a life path not just for an individual but also for a community (Tawney, 1926, p. 102).

Lutheranism perceived economic life in a peasant's way, with a certain degree of mysticism. Calvinism was largely an urban movement. It spread throughout Europe mostly thanks to not overly wealthy merchants and artisans who needed credit for their business development more than wealthy merchants did. The existing Christian ethic controlling economic issues (e.g.: borrowing and lending money) was more of a hindrance in their activities than a guide. Those groups sought to liberate the economy and subordinate it to the norms of a different kind that would not remain so heavily dependent on religious morality. Calvinism considered in its teachings the position and aspirations of people involved in trade and crafts (Tawney, 1926, p. 104). As noted by Max Weber, the Protestants, and especially the Calvinists, showed a specific propensity for rationalism, unprecedented among the Catholics, which resulted not from external historical and political determinants but from the permanent internal specificity. A greater detachment of Catholicism from life and certain asceticism of its ideals influenced the indifference of its followers towards the earthly realm. A Catholic cared more for safe and peaceful life, and less for wealth and honours. Referring to the idea that one either eats well or sleeps well, it can be said that a Protestant liked to eat well, while a Catholic preferred to sleep well (1994, pp. 23-25). It is difficult, however, not to see that the Calvinists, especially from the merchant and artisan strata, were sincerely religious and equally ascetic as religious Catholics. The comparison between the Catholic detachment from worldly life, monastic asceticism and ecclesiastical piety and the Protestant participation in the production of goods and capitalist profits showed, however, some inner similarity (1994, p. 26). The Protestant piety freed from the Church and monastic walls became the permanent piety in the world. Hence Weber's statement that the inner relationship between the spirit of Protestantism and capitalist culture must be sought not in the materialistic thinking but in the purely religious characteristics (1994, p. 29).

The Calvinists believed that God demanded from his believers no single good deed but the holiness of the whole life. The religious moral practice was supposed to be a way of life. In the transformation of the entire life, the influence of grace was what lead man into the state of grace. Life's transcendental goal was salvation. Thus, life was completely rationalised and dominated by one principal: Making the world a better place was the enhancement of the glory of God. Such a life allowed one to overcome the state of nature as it helped to free a person from irrational drives and impose self-control over one's actions and allowed one to reflect on the ethical consequences on one's actions. Rationalisation endowed the Calvinist religiousness with its specific, ascetic qualities (Weber, 1994, pp. 103-105).

A conscious life was supposed to be orderly and harmonious, far from thoughtless living, and an ascetic way of life served that purpose. In Catholicism, the more ascetic life man led, the more distant from the everyday life he became. A Catholic's holy life was to consist in overcoming obstacles of everyday life. 
This discrepancy between holy life and secular life was cancelled by Martin Luther, and Calvinism followed in his footsteps. People who were focused on their inner lives, instead of gathering in monasteries, could realise their ascetic ideals in their worldly lives because of Calvinism. The Calvinist faith was supposed to be practised especially in everyday working life. The spiritual aristocracy of monks was to be replaced with the spiritual aristocracy of the predestined by God in this world (Weber, 1994, pp. 107-108).

John Calvin, the Reformer, had a strict approach to economic issues, although with a high degree of understanding of human material aspirations. In contrast to Luther, he did not consider the world of people's material motivations with such great suspicion and did not perceive economic issues as completely devoid of influence on spirituality. Luther's approach to economic issues had a traditionalistic character, which was a result of belief in predestination also in the simplest life matters. The man was supposed to stay in the condition and profession that God ordained and in his earthly ambitions were not to exceed his social status. The faith in predestination meant to Luther obedience to God along with unconditional submission to the existing situation. Luther stopped short of the new approach combining work with religious principles, the idea of testing one's religious stance in the proper way of living and working, which was so important for the Calvinists (Weber, 1994, pp. 69-70).

The doctrine of predestination, associating salvation solely with the grace of God encompassing only the predestined ones, resulted in the recognition of human efforts as inconsequential in the matter of salvation. According to Calvin and his successors, the meaning of human life on earth was not salvation but praising the glory of God through prayer, and, above all, through action. Through toil and labour the "sanctification" (renewal) of the world was to be achieved - the main goal of earthly life. The ability to carry out such methodical work was a proof of predestination and was recognised as a sign of being predestined, justified from sin by grace. The grace of God was a gift, not a reward. According to Calvin: "[...] the gift of good works [...] shows, that we have received the Spirit of adoption" (2008, Book III, Ch. 14:6-11, 16). Grace had, therefore, a transformational quality - making people presented with that gift capable of transforming their own lives (McGrath, 2009, p. 336). The followers of Calvinism were convinced that the duty of a Christian was to discipline one's private life and create a "sanctified" society in which individual duties were performed by people aware that they were constantly watched by the Creator and that their time was inexorably passing (Tawney, 1926, pp. 108-109). In the eyes of God, a form of life that was useful to society was the worthiest of praise. Christians were encouraged, and even forced, to become engaged and involved in the world. Calvin's teachings may be called "anti-theological theology" in the sense that his concept was not associated with the complete absence of theology but rather with the clear emphasis on the affirmation of the world. The secularisation of sanctity present in Calvin's thought 
assumed the enclosing of the sphere of human existence within the limits of divine sanctification and human sacrifice. The main pillar of that kind of life was to be the sanctification of work (McGrath, 2009, p. 311).

How to recognise who is predestined and who is not? Although Calvin stressed that good deeds were not the foundation of salvation, he did not oppose their perception as the basic elements of salvation. He stated: "Conscience being thus founded, built up, and established, is farther established by the consideration of works, inasmuch as they are proofs of God dwelling and reigning in us" (2008, Book III, Ch. 14:18). Anxiety and uncertainty concerning the salvation of the soul associated with predestination were a sign of Reformed spirituality. Calvinist preachers and theologians pacified the faithful, preaching that by fulfilling their daily duties and living in accordance with the precepts of religion, they were in fact the predestined ones, as good life was treated as a consequence of salvation. Thus, there was a psychological emphasis on proving one's own predestination to oneself and to the world by showing certain signs, such as praising God through conscientious work in His world (McGrath, 2009, pp. 338-339). Therefore, there existed a certain compulsion to demonstrate one's predestination. The doctrine of predestination, which says that human salvation or condemnation is predestined by the will of God, might have seemed cruel and resulted in quietism, abandoning any attempts and efforts, as well as in submission to the judgment of the Almighty God. In practice, however, the situation was reversed-in the effort to follow the signs of salvation, man constantly undertook activity in the world (McGrath, 2009, pp. 340-341). Calvinism created a completely different than in Catholicism and Lutheranism relationship between religious life and worldly activity. Especially because of the Puritans, a radical turn to the material realm was made, and earthly life was interpreted as a task (Weber, 1994, pp. 72-73).

A new attitude to work, especially physical labour, is one of the most important aspects of Calvin's legacy. Until the time of the Reformation, physical labour was treated as a necessity, a repulsive and degrading activity. Such an attitude towards work was the remnant of ancient Greece, in which the sphere of private life (gr. idion), including also physical labour (usually performed by slaves), was considered as the domain of necessity contrasted with the political sphere seen as the domain of freedom. Aristotelianism, followed by Thomist philosophy, recognised work as a means to satisfy one's needs, and thus to achieve happiness. The principle of the golden mean called for moderation, maintaining the balance between work and leisure. Work was not considered as valuable in itself but as a means to meet human needs.

In all the Protestant denominations, the performance of duties within secular professions was evaluated from the moral point of view. This novel approach was a consequence of attributing religious significance to secular daily work. The concept of the profession-vocation was created. The moral improvement was perceived as the centre of life accepted by God. The improvement, however, was to be achieved not by means of earthly monastic asceticism but by the fulfilment of earthly duties arising from the position of each person. In teachings of Luther, convinced of the necessity of man's obedience to any authority and his 
submission to a designated life role and situation, the idea of the profession as a vocation, though stressed, did not affect the relationship between the religious stance and the practice of everyday life (Weber, 1994, pp. 64, 72). The situation was different in Calvinism.

Calvinism radically changed the approach to work, especially physical labour (Rothbard, 2006, pp. 141-142). It became the activity the worthiest of recognition among all the other activities, since work was treated not as a paid occupation but as a careful and productive use of talents and capabilities that man was endowed with. Work was seen as a spiritual activity, as a socially beneficial form of prayer (McGrath, 2009, p. 344). A truly religious Calvinist treated work not as a source of income but as an activity which had value in itself. As noted by Weber, this way of thinking could not be the consequence of low or high remuneration but rather a result of a sort of educational process (1994, pp. 43-44). It was associated with the process of "rationalisation of religion", i.e. stripping religion of magical and irrational forms of search for salvation in favour of focusing on the world (and acting within the worldly sphere). Asceticism was pulled out of monasteries and work became an ascetic means par excellence (Weber, 1994, p. 121).

Work acquired a special significance among the late Calvinists-the Puritans. In this context, it is worth mentioning Richard Baxter and Benjamin Franklin. Richard Baxter's Christian Directory is a compendium of Puritan moral theology. As a Puritan, Baxter drew readers' attention to the issue of time, its waste was recognised as the first and greatest sin. Life was perceived as too short to spend time on idle talk, entertainment, luxury, or long sleep. Thus - in his opinion-man wasted his vocation. Idleness was equally sinful for Baxter. The apotheosis of hard work was encountered throughout his major work (Weber, 1994, pp. 145-150). Similar teachings were found in Benjamin Franklin's Poor Richard's Almanac. It praises hard work, frugality, honesty, honouring a given word, and respecting time, i.e. the values which, according to Weber, while followed created the spirit of modern capitalism. Some of the statements made by Franklin are widely known ("Remember, that time is money", "Money can beget money", "Have you somewhat to do tomorrow; do it today", "Therefore never keep borrowed money an hour beyond the time you promised, lest a disappointment shuts your friends' purse forever", "The way to wealth leads through industry and frugality", "Without industry and frugality nothing will do, with them, everything", "Early to bed and early to rise makes a man health, wealthy and wise", "Diligence is the mother of good luck", "Half a truth is often a great lie", "Well done is better than well said") (Franklin, 1900, pp. 13, 41-42, 44-46).

\footnotetext{
${ }^{2}$ Weber argued that the rationalisation of religion, already noticeable among the ancient Israelites, was because of the urban strata of craftsmen and merchants (Weber, 2002, pp. 368-369). Within the framework of Calvinism, the process of rationalising religion and ethics derived from it was advanced much further. Industry, frugality, reliability and honouring one's word were elements of rationalised ethic. These ideals were valued by Calvinist small merchants and craftsmen, as these translated into success in their businesses, and thus soothed their anxiety about the salvation of their souls.
} 
Among the followers of the Reformed religion, a positive attitude to wealth dominated as some saw it as a sign of being predestined. The followers of Calvinism in the United States in the $19^{\text {th }}$ century were characterised by this approach. John D. Rockefeller, Sr. thought of his fortune as a sort of divine reward for his faith. Other successful people treated individual and national wealth as a sign of God's grace. The emergence of the "Theology of Prosperity" in the 1970s was seen as a deformed Calvinist work ethic (McGrath, 2009, pp. 354-355).

Regarding poverty, the Calvinists did not distinguish economic and moral motives. Poverty was treated as a result of misfortune or laziness. The remedy was work. Calvin recalled in this context the words of Saint Paul stating that: "The one who is unwilling to work shall not eat" (2 Thes 3:10) (Tawney, 1926, p. 114). The idleness of begging was perceived as a sin against God and a social evil. At the other extreme, he placed merchants' business ventures, their prudence and thrift, treating their economic activity as both a Christian virtue and a material benefit for society. The same combination of religious zeal and practicality was responsible for the attack on gambling, sumptuous clothes or tolerance for lack of moderation in food and drink. The essence of the social science created by Calvin and developed by his successors was an attempt to crystallise a moral ideal of society's daily life. Calvinism abolished monasticism only to make a big monastery of secular reality (Tawney, 1926, p. 115).

As it is known, the Calvinist social ethics had roots in urban entrepreneurship of craftsmen and merchants. Thus, it must have taken a stance concerning the long-debated issue of money lending at interest, known at the time as usury.

Calvin's attitude to usury was, one might say, measured. He believed that conducting financial interests was moral provided the income did not exceed a specified maximum. The security for the money borrowed could not be exaggerated. Calvin considered the interests of both parties. The creditor's profit could not have been so large that it would have made him rich at a rapid pace at the expense of the debtor's excessive effort or so large that the latter would have been left without the profits from his work (Tawney, 1926, p. 106). Loans for the poor were to be interest-free. Calvin emphasised the distinction between a loan for the poor and a commercial loan given for profit, between the profits (or lack thereof) obtained due to the poor people's necessity and the profits that merchants could have gained by lending their capital, for example, to other merchants. He also believed that the income from usury should not be the basis for supporting oneself, and therefore no one should work as a professional moneylender. Calvin's approach changed the direction of debate about money lending, as he believed that the issue should not be considered from the doctrinal perspective but as an element of social relations within a particular Christian community, taking into account the circumstances of a given place and time. The conclusion, resulting from the discussion on money lending taken up by Calvin, was the recognition of credit as a normal and necessary part of social life (Rothbard, 2006, p. 140; Tawney, 1926, p. 107).

The Reformer, referring to the message conveyed in the Word of God, pointed to its ambiguity in relation to usury. He decided that the excerpts of the Old Testament treating usury as a sin against mercy (Exodus 22:25, Leviticus 
25:35-37, Deuteronomy 23:19-20, Ezekiel 18.13, Luke 6:35) were no longer congruent with the realities of those times. In addition, he pointed to an ambiguous attitude to usury on the part of Jews who did not receive interest from credits granted to the Jews but allowed it in respect to non-Jews. He did not agree with the argument raised by Aristotle (2003, Book I, 3:19), who noted that money was "sterile", i.e. it could not multiply as wheat or cattle, hence the lending of money at interest was contrary to nature, as it contributed to their "multiplication". "Infertility" of money resulted, according to the philosopher, from the fact that it was not a natural phenomenon as exchange was, but it was created by the law as a means of exchange. Exchange itself existed as something natural and original. According to Calvin, the payment for the use of capital was as reasonable as the payment for the lease of land. He left to an individual's conscience the decision whether the size of the payment was not contrary to the sense of fairness. Calvin hoped that people would be moderate in their commercial ventures, using their Christian common sense. His economic beliefs were part of process of acceptance of commercial realities and related aspirations, also financial ones, spreading among his contemporaries (Tawney, 1926, pp. 107-108).

The Dutch Calvinist Claude Saumaise (Latin name: Claudius Salmasius; 1588-1653) went much further in his reflection on usury. In several works published in Leyden in the years 1630-1645, began by De usuristiber in 1630, Salmasius put an end to the dilemmas related to interest derived from loans. He clearly stated that money lending at interest is an economic activity which, as any other activity, had a price regulated by market competition. Salmasius also had the courage to conclude that there were no axiological arguments against usury, that such arguments could not be deduced either from the law of God or the laws of nature. Although, based on the Old Testament, the Jews forbade usury against other Jews, but that prohibition was rather a political or tribal act than an expression of specific morality referring to economic transactions. Jesus did not teach anything about politics or economics. According to Salmasius, the law banning usury was only the Pope's will, hence the Calvinists were not required to abide by it (Tawney, 1926, p. 144). In Salmasius's opinion, usury was a sort of compensation for, first of all, the inability to use the lent money, and also for the risk associated with the possibility of its loss. Salmasius also voiced his opinion on the controversial issues of lending money to poor people at interest. He said that the poor should be treated as any other borrowers. He argued that the seller of bread was not required to ask the customers if they were rich or poor, why, therefore, such a duty should be imposed on money lenders? (Tawney, 1926, p. 145)

\section{Conclusions}

The separation of the material and spiritual realm as well as the state of nature and the state of grace made on the basis of the Protestant theology as a consequence of original sin combined with the principle of predestination had a great social signi- 
ficance. In the world of earthly life, it was impossible to find the means that could be used to receive God's grace, i.e. salvation. Martin Luther and the followers of Lutheranism saw such a state of affairs as a reason for renouncing worldly aspirations, instead focusing on personal spirituality, leaving the worldly affairs to the secular power whose mission was to limit evil by means of the sword. A completely different approach to the said dualism was represented by Calvin and his successors, especially the Puritans. Their position can be defined as the affirmation of the earthly reality and the desire to make the world a better place based on religious pragmatism associated with rationalising religious ethics and endowing it with utility-related properties. Thanks to Calvinism, from the onset affirming the world, considerable progress in the approach to the economic sphere, especially to the matter of work and circulation of money, was made. Especially the late Calvinists, the Puritans, created on the foundation of religious values a work culture based on conscientiousness, honesty and honouring one's word. Weber in his The Protestant Ethic and the Spirit of Capitalism wrote that the question concerning the forces driving the development of modern capitalism is first and foremost the question not about the source of the necessary money but about the development of the spirit. Wherever the spirit of capitalism was alive, it found financial resources as a means of its operation, but never the other way around (Weber, 1994, p. 49).

\section{References}

Aristotle (2003). Polityka (L. Piotrowicz, Trans.). In Arystoteles, Dzieła wszystkie, Vol. 1. Warszawa: Wydawnictwo Naukowe PWN.

Calvin, J. (2008). Institutes of the Christian religion (H. Beveridge, Trans.). Peabody: Hendrickson Publishers.

Franklin, B. (1900). Poor Richard's Almanac. New York-Boston: H. M. Caldwell. http://ar chive.org/details/poorrichardsalm01frangoog

Hervada, J. (2013). Historia prawa naturalnego (A. Dorabialska, Trans.). Kraków: Petrus.

Luter, M. (1517). Disputation against Scholastic theology. http://augsburgfortress.org/me dia/downloads/9780800698836kChapter1.pdf

McGrath, A. E. (2009). Jan Kalwin. Studium ksztaltowania kultury Zachodu (J. Wolak, Trans.). Warszawa: Wydawnictwo Naukowe Semper.

Rothbard, M. N. (2006). Economic thought before Adam Smith. An Austrian perspective on the History of Economic Thought (Vol. 1). Auburn: Ludwig von Mises Institute.

Tawney, R. H. (1926). Religion and the rise of capitalism. A historical study. New York: Harcourt. Brace and Company. http://quod.lib.umich.edu/g/genpub

Trueman, C. R. (2004). Calvin and Calvinism. In D. K. McKim (Ed.), The Cambridge companion to John Calvin. Cambridge University Press. 
Weber, M. (1994). Etyka protestancka a duch kapitalizmu (J. Miziński, Trans.). Lublin: Wydawnictwo Test.

Weber, M. (2002). Gospodarka i spoteczeństwo. Zarys socjologii rozumiejacej (Preface and translation by D. Lachowska). Warszawa: Wydawnictwo Naukowe PWN. 